\title{
Mortgaging Europe's Periphery
}

\author{
Dorothee Bohle ${ }^{1}$
}

Published online: 25 April 2018

(C) The Author(s) 2018

\begin{abstract}
This paper asks why peripheral European countries have been particularly vulnerable to housing and mortgage booms in recent decades; how these booms have shaped their exposure to the global financial crisis (GFC), and how the GFC has affected peripheral housing finance. To answer these questions, it explores the interaction between European processes of financial integration and domestic housing (finance) policies in four peripheral countries. It argues that the EU framework for free movement of capital and financial service provision as well as the availability of cheap credit has induced a trajectory of housing financialization, which has taken two forms: funding from wholesale markets and direct penetration of foreign financial institutions. These two forms attest to a core-periphery relationship in housing financialization, whose hierarchical character came to the fore in the crisis. Peripheral European countries experienced sudden stops and reversals of capital flows, which badly affected their banking systems. Unable to solve the looming banking crises on their own, they had to turn to creditors to gain access to much needed capital. A combination of international conditionality and domestic policy responses, and the original level of mortgage debt result in different trajectories in housing finance after the crisis.
\end{abstract}

Keywords Housing · Financialization · Financial crisis · European periphery

\section{Introduction}

Why have the biggest European mortgage and housing booms and busts prior to the global financial crisis (GFC) occurred in the continent's periphery, rather than its core? How have mortgage and housing booms affected these countries' vulnerability to the GFC, and how has the GFC affected peripheral housing finance? This paper seeks to

An earlier version of this paper was presented at the "EU Integration and Diverging Pathways from the Periphery" workshop at the European University Institute, November 20-21, 2015.

Dorothee Bohle

Dorothee.bohle@eui.eu

1 Department of Political and Social Sciences, European University Institute, Florence, Italy 
understand the development of housing finance in peripheral European states. A small but growing body of scholarly literature has established the centrality of housing finance in contemporary capitalism. Housing has become a most significant absorber of global liquidity, and innovations in housing finance have been identified as the root cause of the GFC (e.g., Schwartz and Seabrooke 2008; Schwartz 2009; Ansell 2014; Aalbers 2016). At the same time, national housing systems differ in how far they have been integrated globally, the liquidity of their mortgage markets, and their reliance on housing as a social protection mechanism (Schwartz and Seabrooke 2008; Schelkle 2012). While originally the literature associated volatile housing markets and soaring mortgage debt with the Anglo-American liberal market economies, recent work has shown that these phenomena cross-cut established varieties of capitalism (ibid.). The research has so far, however, mostly focused on advanced capitalist countries.

This paper seeks to probe further into the differences of residential capitalisms in Europe, and their pre- and post-crisis trajectories. Specifically, it seeks to establish communalities and differences among peripheral housing finance regimes in Europe. The paper argues that high homeownership rates and unsophisticated mortgage markets have characterized all of Europe's East, South, and peripheral Northwest. Since the 1990s, the evolving EU framework for free movement of capital and provision of financial services as well as the availability of ample and cheap credit has induced a trajectory of financialization in these countries. Financialization has taken two major but not mutually exclusive forms: domestic banks' reliance on (increasingly short-term) funding from wholesale interbank markets and direct penetration of foreign financial institutions setting off a-mostly foreign currency-mortgage lending boom. These two forms of financialization attest to a core-periphery relationship, whose hierarchical character came to the fore during the crisis. Most peripheral European countries experienced sudden stops and reversals of capital flows, which adversely affected their banking systems. Not having a domestic lender of last resort able to solve the looming banking crises, they had to turn to international creditors to gain access to much needed capital. A combination of international conditionality and domestic policy responses, and the original level of mortgage debt have resulted in different trajectories in housing finance after the crisis.

While the paper focuses on similarities in housing finance trajectories, it also accounts for the differences in timing of financialization, origins of homeownership regimes, and policy responses. It does so by tracing the emergence of peripheral housing finance regimes, and their pre- and post-crisis trajectories with four in-depth case studies-Hungary, Latvia, Iceland, and Ireland. This mix of East and West European countries with different housing finance legacies and institutions, and different degrees of integration in the EU, reflects the diversity of Europe's periphery. ${ }^{1}$ Yet, despite their differences, all four countries have experienced major housing and mortgage booms, and all of them are still reeling from the impact of the GFC on housing and housing finance.

The paper is organized as follows. The next section reviews existing literature, establishes the puzzle, and develops the analytical framework. The third section traces the origins of housing and mortgage booms in the four peripheral European countries, and section four analyzes crisis exposure and responses. The last section concludes.

\footnotetext{
${ }^{1}$ This paper does not cover Southern European cases in its analysis. Yet, most of the arguments made here can also be extended to Spain and to a lesser degree to Portugal and Greece.
} 


\section{Mortgage Finance and Housing in (European) Capitalism}

One of the biggest puzzles of the EU's crisis management and new economic governance is that it focuses almost exclusively on reining in public debt and increasing competitiveness, while much of the crisis build-up was linked to private debt, and specifically mortgage debt (IMF 2012; Jordà et al. 2014). Thus, many countries that were hard hit by the crisis had very high outstanding mortgage debt. In Europe, it was Iceland that had the highest mortgage debt relative to GDP. Iceland's public debt in 2007 was $28 \%$ and residential mortgage debt was $119 \%$. The close second and third groups were the Netherlands and Denmark with almost 100 and 93\%, whereas their public debt stood at 42 and $27 \%$, respectively. Among the peripheral European countries, the level of residential mortgage debt surpassed that of the public debt in Spain, Ireland, Iceland, and the Baltic States. ${ }^{2}$ Even in those countries where this was not the case, the level of mortgage debt has increased significantly over the 2000s. ${ }^{3}$ Indeed, even more stunning than the level of mortgage debt has been its increase over the last (two) decades. Figure 1 depicts the increase of mortgage debt and house price increases prior to the GFC. It shows that mortgage and house-price booms have been the strongest in East Central European countries, followed by Europe's Western periphery. Compared to the periphery, core countries' house price and mortgage lending increases seem rather moderate.

Of course, the three country groups are not homogenous. Among the core countries, the UK had the highest house price and mortgage lending boom, and not all peripheral countries have experienced major lending booms. Figure 2 further details mortgage lending in the sample of peripheral countries. Here, three groups of countries can be identified: the first group had already experienced a boom in mortgage debt during the 1990s - as witnessed by relatively high mortgage debt in 2002 - and still registered high growth rates during the first decade of the 2000s. Incidentally, these are all western peripheral countries. The second group of countries started with almost no mortgage debt in 2002 and registered very high growth rates until 2008. These are mostly East Central European countries. Finally, the third group, made up of both western and eastern peripheral countries did not experience much increase in their mortgage debt. All in all, it is fair to say that a large majority of peripheral European countries experienced very high mortgage lending growth rates during the early 2000s.

Despite the centrality of housing and housing finance in the GFC, the specific challenges of peripheral housing regimes have not yet been well understood. A small but growing literature that investigates the centrality of housing and mortgage debt for contemporary capitalism provides an important starting point to the inquiry. Thus, in their pioneering work, Schwartz and Seabrooke (2008) and Schwartz (2009) distinguish between four varieties of residential capitalism (VoRC). The first, "liberal market" type is characterized by high levels of house ownership, mortgage debt, and liberal mortgage markets; and contrasts with the "statist-developmentalist" capitalism

\footnotetext{
${ }^{2}$ The use of the term of European core and periphery has become more common in the wake of the Euro crisis, acknowledging the fact that some European countries had been subject to much more destabilizing capital inflows than others. In line with this, I use the term core countries for Europe's North Western advanced capitalist countries, and peripheral countries for the East Central and Southern European countries, as well as Ireland and Iceland.

${ }^{3}$ The data for mortgage debt are from EMF (2011); the data for public debt are from Eurostat.
} 


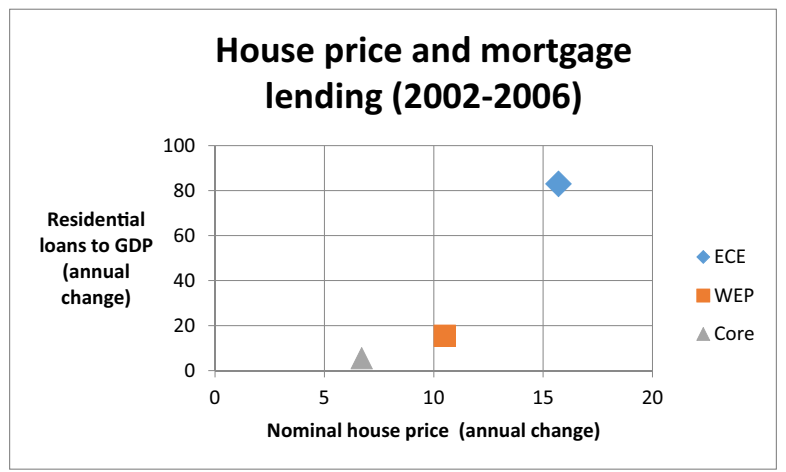

Fig. 1 House price and mortgage lending (2002-2006). ECE countries are the Czech Republic, Estonia, Hungary, Lithuania, Poland, and Slovenia; Western European peripheral (WEP) countries are Greece, Italy, Ireland, Portugal, and Spain; and core countries are Austria, Belgium, France, Denmark, Germany, Norway, Sweden, and the UK. Data for house prices are from Égert and Mihaljek 2007 and EMF 2014, data for residential loans from EMF 2013

with low levels of owner occupation, mortgage debt, and highly controlled mortgage markets. The "corporatist-market" capitalism has low levels of homeownership but high levels of mortgage debt despite relatively controlled mortgage markets, whereas "familial residential" capitalism has very high homeownership levels but low mortgage debt. Interestingly, except for the Czech Republic, all European peripheral countries considered by Schwartz and Seabrooke cluster in the familial type of residential capitalism. Table 1 summarizes their typology.

While Schwartz and Seabrooke's typology is crucial for understanding the starting point of peripheral (or familial) housing finance regimes, it does not provide an answer to the question as to why it was these regimes that have experienced massive credit growth over the last two decades. To seek an answer, I turn to the work of Manuel Aalbers and his co-authors on the financialization of housing, which complements Schwartz and Seabrooke's work (Aalbers 2008; Aalbers and Christophers 2014; Fernandez and Aalbers 2016; Aalbers 2016). Building on heterodox analyses of

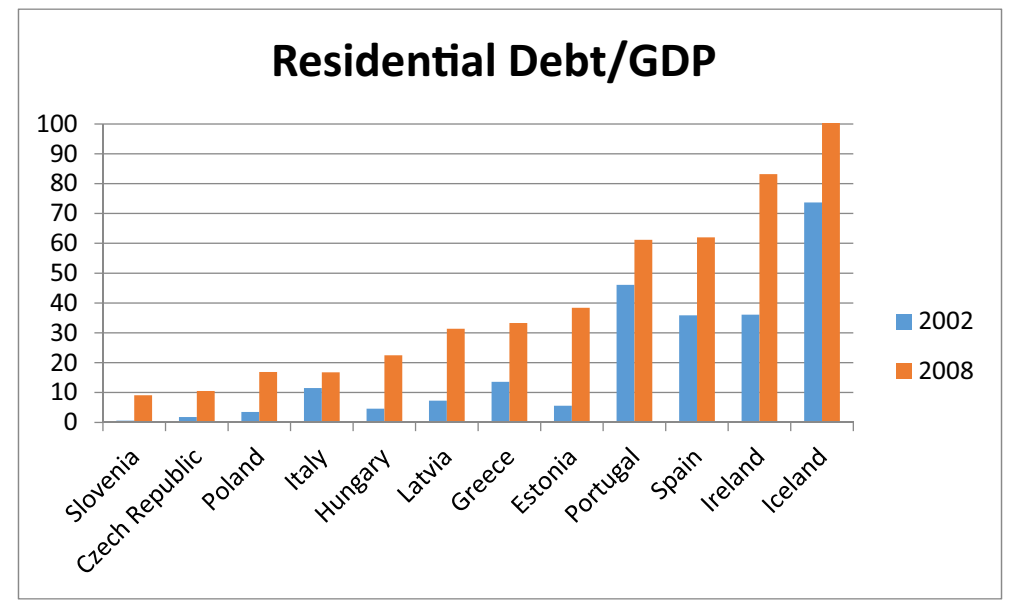

Fig. 2 Residential debt/GDP. Source: EMF 2013 
Table 1 Varieties of Residential Capitalism

\begin{tabular}{llll}
\hline & & Owner occupation rate & \\
& & Low & High \\
\hline \multirow{2}{*}{ Mortgage as \% of GDP } & High & Corporatist-market & Liberal market \\
& Low & Statist-developmentalist & Familial \\
\hline
\end{tabular}

Source: adapted from Schwartz and Seabrooke 2008: 244

financialization, Aalbers argues that in the last one to two decades, a "global wall of money" - a global pool of liquid capital that looks for investment opportunities - has been built up. The global wall of money results from the rise of accumulated corporate profits which are not being reinvested in the real economy or shared with workers, the recycling of trade surpluses of emerging and export-oriented economies, and the privatization of pension schemes and build-up of funded pensions. Housing and mortgage debt, which are considered high quality collateral, have absorbed an increasing amount of liquidity (Schwartz 2009; Fernandez and Aalbers 2016).

While privatization, deregulation, and the wall of money have induced a common trend towards more financialized housing finance, these processes are filtered by national institutions and policies. Fernandez and Aalbers (2016) sketch four different trajectories. Not surprisingly, there is a strong affinity between these trajectories and the VoRC as identified by Schwartz and Seabrooke. Thus, somewhat simplified, Fernandez and Aalbers find that the liberal market and corporatist-market varieties have embraced financialization, while in the statist-developmentalist and familial varieties, the transformation of the housing and housing finance regimes has not yet reached the critical point of financialization. Aalbers and Fernandez are not concerned with building typologies, however, but rather with identifying a set of trajectories of housing centered financialization.

My paper will delve further in examining trajectories of housing-centered financialization by focusing on the similarities and differences among the trajectories of peripheral —or familial — varieties of residential capitalism. ${ }^{4}$ In order to get to the specificities of the mortgage lending booms across Europe's periphery, and to assess the post-crisis fate of financialization, this paper will build on VoRC's insight that familial housing (finance) regimes are set apart, and combine this with digging deeper into the mechanisms of "subordinated financialization" (Lapavitsas 2013), where peripheral countries are joining an increasingly financialized world economy while lacking the state power and capacities for shaping the processes of financialization. To this aim, I study four cases that have experienced major mortgage and housing booms during the 2000s. My case selection includes two peripheral countries that, according to Fernandez and Aalbers (2016), have crossed the threshold of housing financialization-Ireland and Iceland - and two that have not—Latvia and Hungary. These countries are also representative of the diversity of Europe's peripheries. Located

\footnotetext{
${ }^{4}$ I use peripheral and familial housing regimes interchangeably. As will become clear in the "Peripheral Homeownership Regimes Meet Transnational Financial Markets" section, the reliance on family resources for housing finance is related to these countries' peripheral late industrialization.
} 
in Europe's East and West, they represent different varieties of capitalism, and are integrated in different ways in the European economy.

I seek to make four contributions to the existing literature. First, I include the trajectories of East Central European housing finance in a debate that so far has mostly focused on the West. Second, I further explore specificities of peripheral financialization. Third, I analyze recent changes by studying the interaction of the transnational liberalization of finance and domestic housing and housing finance policies. This way, I open the "black box" of housing finance institutions and policies, and show how they have developed over time. Fourth, I go beyond the build-up of the mortgage boom to ask how the GFC has affected housing finance in Europe's periphery.

\section{Peripheral Homeownership Regimes Meet Transnational Financial Markets}

As Schwartz and Seabrooke (2008) note, there are some features that set the European familial variety of residential capitalism apart from the advanced capitalist world. To put it in a pointed fashion: most European peripheral countries started their journeys in the world of transnational finance as debt-free or financially repressed high homeownership societies. That is, while the owner occupation rate in Europe's periphery is significantly higher than in the core, mortgage debt has traditionally been much lower, and/or mortgage lending has not been market-based. Thus, homeownership rates in the periphery in 2000 ranged from more than $75 \%$ in Portugal and Ireland to around 90\% in Spain, Iceland, Hungary and Romania. Concomitantly, these countries have among the smallest rented sectors in Europe, and virtually no social renting (Allen et al. 2004; Sveinsson 2011; Hegedüs 2013; Norris 2016).

In the western and southern European periphery, high homeownership rates predate the neoliberal turn towards private homeownership, and are closely related to the role of late and limited industrialization and weak state capacity that are characteristic of the periphery. In core Europe, the promotion of a social rental sector aimed at accommodating the urban industrial labor force and is associated with large public or cooperative ownership (e.g., Esping-Andersen 1988). In contrast, late and limited industrialization in the periphery decreased the pressure for accommodating masses of new city dwellers. At the same time, the peripheral states often lacked the capacity to finance and manage a big rented sector (Allen et al. 2004: 166). Promoting homeownership rather than social rentals was also a device to achieve social stability (Allen et al. 2004; Dellepiane et al. 2013; Norris 2016). Europe's western periphery came to high homeownership via limited or highly decommodified mortgage debt. Norris (2016) coined the term "socialized homeownership regime" for Ireland to denote the generosity of state subsidies for private homeownership. Similar socialized homeownership regimes also were in place in Southern Europe and Iceland (Allen et al. 2004; Sveinsson 2011).

The Eastern European road to high owner occupation without mortgage debt was different. While Eastern Europe was industrializing late too, it achieved an industrial break-through behind the protective walls of state socialism. The communist ideology and its bureaucratic form of governance, rapid industrialization and urbanization, and 
heavy war destruction all implied that the state took a leading role in providing large scale housing after the World War II. The high homeownership rates in Eastern Europe are therefore a direct result of transition policies after 1989. Indeed, transferring the predominantly public housing stock into private hands was among the first steps undertaken by post-communist governments, often in close collaboration with international financial organizations such as the World Bank (Hegedüs 2013; Stephens et al. 2015). In this sense, it can be argued that their past as late industrializers caught up with post-communist Eastern Europe: after 1989, private homeownership was considered the norm, and large scale public housing stock a socialist aberration.

In Eastern Europe, even more than in peripheral Western Europe, high homeownership rates were achieved despite the absence of liberal mortgage markets. With transnational deregulation of the financial sector and the build-up of the wall of money, things started to change. In Europe, it was the EU's initiatives towards financial market integration that channeled an increasing share of the global wall of money through banks to Europe's periphery and specifically its mortgage markets. Most important in this respect was the Single Banking License, which entered into force in 1993, and enabled European banks to establish branches and provide cross-border financial services in the EU and European Economic Area (EEA) (Decressin et al. 2007). At the same time, the EU Directives on Own Funds and Solvency Ratio, which took effect in 1993, "introduced a preferential weighting for residential loans and significantly increased the lenders' ability to finance mortgage credit" (Whitehead et al. 2014: 10). The introduction of the euro eliminated the currency risk and pushed for further regulatory convergence among members of the eurozone. In addition, interest rates set by the European Central Bank (ECB) made borrowing for peripheral eurozone members disproportionally cheap, often resulting in negative real interest rates (Honohan 2010: 11; Hay et al. 2008). All of this fueled cross-border lending, allowing the banks of peripheral states to escape their narrow deposit base, and made financing of mortgage credit much easier.

This is the background against which most of the West European peripheral countries started to experience major mortgage lending booms from the 1990s onwards, and Eastern Europe joined during the 2000s. The remainder of this section will look more in detail at how mortgage and housing booms unfolded in Ireland, Iceland, Hungary, and Latvia.

\section{Mortgage Booms in Ireland and Iceland}

Both Iceland and Ireland are infamously known for the stellar rise of their banking sectors during the 2000s. In 2008, the banking systems' total assets amounted to a staggering $800 \%$ of GDP in Iceland and close to $700 \%$ in Ireland (Eckholdt Christensen 2011: 116). In Ireland, the rapid growth of the banking sector was intrinsically linked with a property and mortgage boom. In Iceland, banks have been most famous for their international shopping spree. But also here, housing finance has played a major role.

In both countries, the dismantling of the socialized homeownership regime (Norris 2016), combined with the deregulation and transnational integration of the banking sector, led to unsustainable mortgage lending booms. In Ireland, a major crisis in the 1980s made the government turn away from publicly subsidizing homeownership. 
Instead, it began to deregulate mortgage finance. As a consequence, private banks moved into the mortgage market, replacing the earlier system dominated by mutual building societies and local governments (Kelly and Everett 2004; Norris and Coates 2010; Dellepiane et al. 2013). From 2003 onward, Irish banks started to rely heavily on interbank lending not only from the euro area, but also the USA and UK (Honohan 2010; Lane 2015). Figure 3 shows the development of foreign claims of BIS-reporting banks for all four countries since 1994. Before the GFC, there had been a rapid increase of foreign claims everywhere, but the levels differ. In Ireland and Iceland, the claims exceeded $300 \%$ of GDP and in Hungary and Latvia they were around $100 \%$. $^{5}$ Figure 3 also shows the sudden stop of foreign claims once the crisis hit, a development I will return to later in the paper.

The established Irish banks also faced fierce competition by new foreign entrants that started to expand aggressively_most infamously Anglo-Irish Bank. Competition as well as a pronounced lack of regulation fostered reckless lending practices (Dellepiane et al. 2013; Lane 2015). Policy makers did little to rein in risky lending practices. It was only in 2003 that the Irish Financial Service Regulatory Agency was established, and its independence from the Central Bank as well as the shortage of skilled staff made it an utterly useless agency (Barnes and Wren 2012). The government, in turn, fueled the housing boom by tax incentives. In this context, it is worth mentioning that the Irish property and housing boom was greatly enhanced by a cozy relationship between the main banks, politicians of the ruling Fianna Fáil party, and developers, a relationship that dates back to the earlier phase of the social homeownership regime (McDonald and Sheridan 2008; Dellepiane et al. 2013).

In comparison to Ireland, Iceland was a latecomer both in terms of banking and mortgage deregulation. The seeds of Iceland's ultra-liberal finance regime were also sown in the 1980s, when a radical neoliberal faction emerged within the ruling Independence Party. The end of the Cold War swept a prominent member of that faction, David Oddson, to power. He was a Prime Minister from 1991 to 2004, and subsequently became the Governor of the Central Bank. It was under his leadership that the Icelandic financial sector was unleashed. The first important step was Iceland's accession to the EEA, which lifted restrictions on cross-border capital flows. Bank privatization followed suit (Wade and Sigursgeirsdottir 2010: 12). Privatization and deregulation enabled investment banks to enter the commercial banking markets, gain access to consumer deposits, and resulted in a heavily concentrated banking sector (ibid; Schwartz 2011).

The newly privatized banks soon began to expand into the mortgage market, hitherto dominated by the government-backed Housing Financing Fund (HFF) (Schwartz 2011: 296). Banks started to offer increasingly attractive loans, and competition over mortgage provision started in earnest when the government relaxed the rules for mortgage lending in 2004. From then on, Icelandic homeowners faced increasingly favorable borrowing conditions. The newly privatized banks out-competed each other and the HFF by offering housing loans with $90 \%$ of the purchase price or more, longer maturities, and lower interest rates. The option of refinancing loans gave homeowners

\footnotetext{
${ }^{5}$ Not all of Ireland's cross-border lending was channeled into the housing market. Ireland's high level of foreign claims is closely linked to its position as an offshore financial center, which it has developed since 1987 (Tax Justice Network, 11/11/2015).
} 


\section{Consolidated Foreign Claims of BIS reporting banks (\% of GDP)}

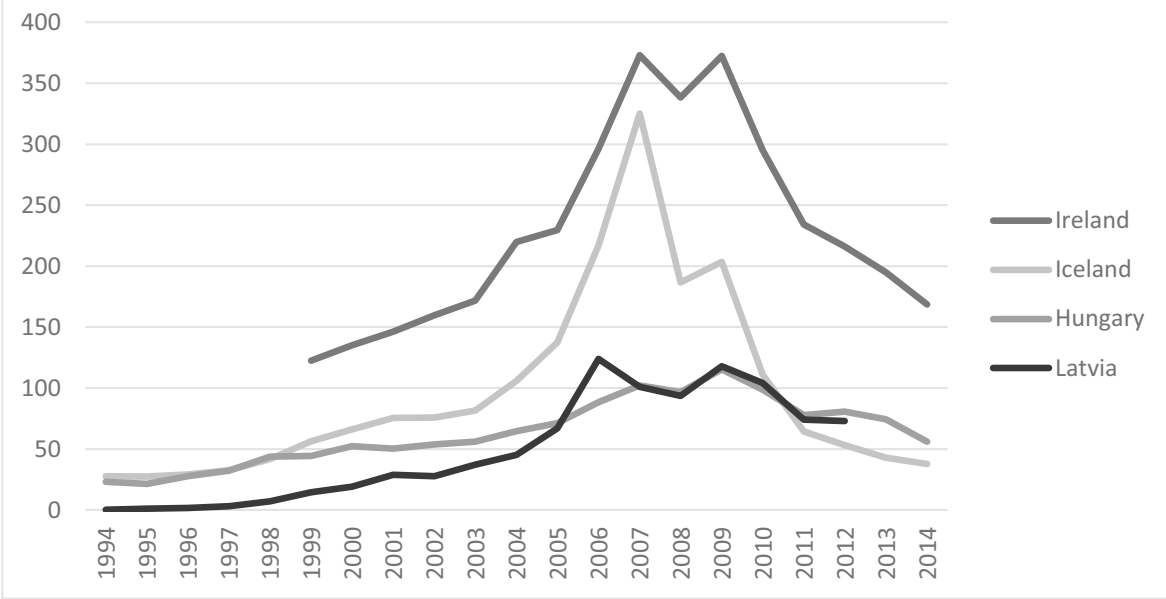

Fig. 3 Consolidated foreign claims of BIS reporting banks (\% of GDP). Source: Worldbank and BIS Global Financial Development Database, http://www.worldbank.org/en/publication/gfdr/data/global-financialdevelopment-database

the possibility to withdraw some of the home equity, and to lower their repayment costs by taking new loans with more favorable conditions. Banks also aggressively pushed homeowners to convert existing loans or take out new ones in foreign currencies, mostly Swiss francs and Japanese yen, in order to take advantage of the lower interest rates. As in Ireland, the rapidly increasing availability of cheap credits fueled a house price boom (Benediktsdottir et al. 2011; Schwartz 2011; Sveinsson 2011; Viken 2011; Hart-Landsberg 2013).

As well known, not only did Icelandic banks lend recklessly at home, but they pursued even more reckless practices abroad. Arguably, the Icelandic elites bought even more into the idea of light touch regulation than their Irish counterparts. Iceland's financial supervision was fragmented between three government departments, the Central Bank, and the Financial Supervisory Authority, which had no functioning cooperation. Even if they had wanted to, it is highly doubtful whether they had the professional skill to exercise supervisory authority (Viken 2011).

\section{Mortgage Booms in Hungary and Latvia ${ }^{6}$}

For Hungary and Latvia, the most important trigger for mortgage lending has been their deep transnational financial integration that went hand in hand with EU accession. The combination of convergence on the institutional and regulative standards of the European financial area, the privatization of the banking sector, and the liberalization of capital movements, all of which were part of EU's entry requirements, allowed these

\footnotetext{
${ }^{6}$ Some of this subsection draws on Bohle 2014.
} 
countries to catch up fast in financial matters (e.g., Enoch and Ötker-Robe 2007; Pistor 2009; Mitra et al. 2010). Most notable is the high share of foreign ownership of their banking sector, a development fostered by the EU, which saw in foreign banks a guarantee for a sound banking system. From the early 2000s onwards, Austrian, Italian, and Swedish banks moved into the region. In the mid-2000s, the asset share of foreign banks was more than $82 \%$ in Hungary and above $60 \%$ in Latvia. ${ }^{7}$

Foreign banks were instrumental in developing the hitherto almost nonexistent mortgage markets. They brought expertise in mortgage lending from their home countries and could easily tap into foreign sources of credit expansion, usually through borrowing from their parent banks. This is reflected in the increase of foreign claims (Fig. 3). In both countries, foreign banks issued loans denominated in foreign currencies, mostly Swiss francs in the Hungarian case and euros in Latvia. Taking advantage of the ECB's expansionary monetary policy in 2004-2007, banks engaged in large scale carry trade of cheap international credit (Aslund and Dombrovskis 2011: 29). For consumers, foreign currency loans were attractive because of the favorable interest rates.

Governments mostly acted in collusion with banks to create more liquid (and inherently more risky) mortgage markets. In Hungary, the first national-conservative government under Premier Viktor Orbán (1998-2002) adopted a program for generously subsidized housing loans and grants for young families to build or buy houses. In addition, people who took a housing loan also received income tax exemption (Rózsavölgyi and Kovács 2005). The continuous expansion of the program, however, turned out to be financially unviable, and was phased out from 2003 (Hegedüs 2011: 119). From this moment on, foreign currency lending really took off. As demand for housing remained very high, low interest rate Swiss franc lending provided a substitute for publicly subsidized mortgage lending (Committee on Constitution, Justice, and Standing Order of the Hungarian Parliament 2012). A very liberal financial environment and strong competition among banks fueled increasingly risky lending practices (Banai et al. 2011; Józon 2015). Despite the fact that the Hungarian National Bank, the Financial Supervisory Authority, and the IMF issued warnings about the foreign currency exposure, Hungarian politicians remained passive on the issue (Bohle 2014).

In Latvia, before the large scale entry of foreign banks, mortgage lending was scarce and expensive, with interest rates between 12 and 14\%. In 2000, the Berzins government adopted the first stage of a housing lending development program, which aimed at encouraging the purchase or renovation of dwellings via subsidized mortgages (Osa 2005: 200). Similar to Hungary, commercial banks' foreign currency lending soon overtook publicly subsidized lending (Henilane 2016: 2). Foreign currency lending seemed a somewhat more natural choice in Latvia than in Hungary. In the early 1990s, Latvia, as a newly independent state, settled on a fixed exchange rate to signal credibility of its new currency to financial markets. It initially pegged the currency to the Special Drawing Rights, and in 2000 to the euro. Latvian governments were also firmly committed to join the euro after its EU accession (Bohle and Greskovits 2012). Latvia's currency peg, limited monetary autonomy, capital convertibility, and informal euroization combined to trigger a major lending and mortgage boom. During the 2000s,

\footnotetext{
${ }^{7}$ http://www.worldbank.org/en/publication/gfdr/data/global-financial-development-database.
} 
Latvia became one of the most financialized economies in East Central Europe. Its growth model relied almost entirely on investment in banking, real estate, and construction (Becker et al. 2010; Bohle and Greskovits 2012). Finance-led growth spurred high inflation rates, and given that Latvia's Central Bank could not use interest rates to rein in inflation, borrowing became increasingly cheaper (Blanchard et al. 2013: 333). Tax policies further contributed to the boom: Latvia did not levy any property tax on residential buildings or capital gain taxes (Aslund and Dombrovskis 2011: 29). No small wonder that Latvians took out increasing volumes of mortgage loans to buy ever more expensive homes. As in Hungary, the IMF and the Central Bank started issuing warnings about the unsustainability of the lending boom (IMF 2006, interview at the Bank of Latvia, Riga, Latvia, 25 September 2015) from the mid-2000s onwards. However, neither regulators nor politicians seemed to be particularly concerned, while banks even stepped up their aggressive lending behavior (interviews with an entrepreneur, Riga, Latvia, 21 September 2015 and with a former cabinet minister, Riga, Latvia, 22 September 2015; Aslund and Dombrovskis 2011; Bukeviciute and Kosicki 2012: 5).

\section{Summary}

This section has identified several similarities but also differences in the build-up of the mortgage booms in peripheral Europe. Differences in EU integration-EMU, EU, or EEA membership - do not seem to imply systematic differences in terms of the mechanisms that have set off the lending booms. In all four countries, EU-induced external liberalization and domestic policies of deregulation and privatization of the banking sector have channeled dominantly international liquidity into mortgage finance. Borrowing in euro reduced the costs of credit significantly for Ireland, as the ECB set interest rates with view of the whole eurozone. However, non-EMU members found functional equivalents, namely borrowing in foreign currency. In all cases, peripheral countries could thus piggyback on interest rates set for much less inflation-prone economies.

Integration in European financial markets - whether as EMU, EU, or EEA member-allowed all four countries to escape the narrow confines of their domestic financial markets. International finance of emerging mortgage markets has taken two forms. In Ireland and Iceland, banks relied strongly on wholesale markets, while in Latvia and Hungary direct foreign bank penetration and the financing of local affiliates through their parent banks played a key role. These differences notwithstanding, both forms led to excessively leveraged banking systems and extensive maturity mismatches, as short-term funds borrowed abroad were invested in long-term mortgages (Schwartz 2011). The four countries were not entirely stripped of regulatory instruments to circumvent the systemic danger inherent in this. Rather, governments and supervisory authorities were either unwilling or unable (and typically both) to curb foreign borrowing and domestic lending and to hedge against the risks.

The high dependence on foreign borrowing proved to be the Achilles heel of the housing finance systems. The next section will explore how the crisis exposed the hierarchical nature of peripheral financialization, and how governments in the four countries responded to the crisis of (mortgage) finance. 


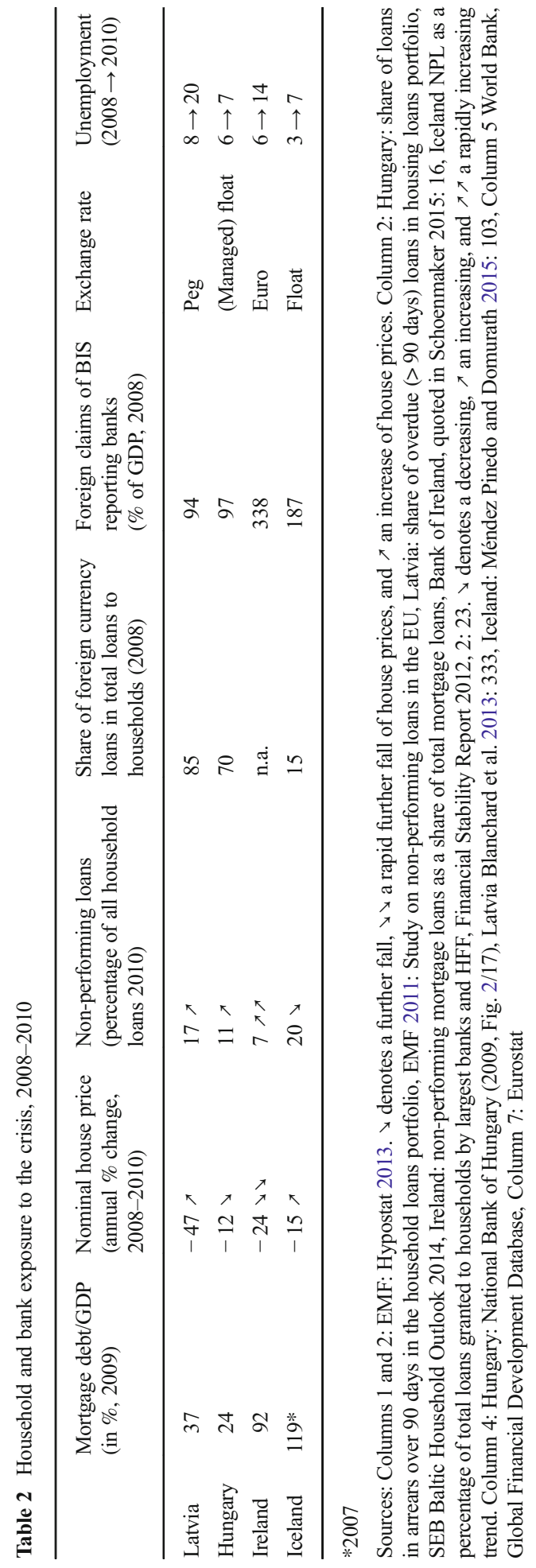




\section{The Mortgage Boom Turns Bust: Crisis and Crisis Management}

Table 2 provides a snapshot view on the exposure of the Latvian, Hungarian, Icelandic, and Irish populations and banks to the housing and mortgage crisis. It reveals that while the depth and mix of the exposure differed across the four countries, in all cases, households have faced increasing risks of over-indebtedness related to rising unemployment and decreasing house prices; and in three cases, they also faced significant exposure to exchange rate risks. All of this resulted in a ballooning of non-performing loans, threatening the stability of the banking sector. High share of foreign debt further endangered the banks.

The financial turmoil from 2008 onwards adversely affected the banking systems. All four countries experienced sudden stops of capital inflows, resulting in sharp recessions (Berthaud and Colliac 2010; Gros and Alcidi 2013; see also Fig. 3), and when the sudden stops turned into liquidity or solvency crises of their banks, Europe's peripheral countries learned who the "ultimate guardian" of their transnationally integrated financial systems was (Pistor 2009). In none of the four countries was the national bank able to act as lender of the last resort. All four countries had to turn to the IMF and/or EU to get access to much needed liquidity, and these organizations coordinated the processes and set the terms for restructuring the financial systems. The terms differed, and governments faced tough decisions on whether to comply with the conditionality or risk being shut off from international markets altogether. Below, I explore how the four countries negotiated the international constraints, choices, and trade-offs that they faced once the crisis broke out, and how these have shaped the housing finance regimes.

\section{Hungary and Iceland: Rejecting Financialization}

\section{Hungary}

Hungary turned to the IMF when its banking sector faced a liquidity crisis resulting from the turmoil in the foreign currency swap market (Aslund and Dombrovskis 2011). Its crisis response evolved in two distinct phases. The first phase was overshadowed by the conditions of the IMF stand-by agreement signed in autumn 2008, and the fear that foreign banks would pull out from the region (Epstein 2014) ${ }^{8}$ It was the so-called Vienna Initiative, a series of accords signed by several East Central European states with ten major European banks and the IMF to maintain the presence of exposed banks that secured foreign bank presence (Pistor 2012). In the agreements, parent banks committed to support their subsidiaries in the region, roll over their credits, and capitalize them adequately. In those countries that had stand-by agreements with the IMF, banks made their commitment dependent on their host governments' compliance (ibid.). Under these conditions, the housing question was not a priority for the

\footnotetext{
${ }^{8}$ In November 2008 , the IMF approved a $€ 12.5$ billion loan to Hungary to help it weather the crisis. The IMFsupported economic program had two key objectives: fiscal consolidation and the stabilization of the financial sector. This was part of a broader IMF-World Bank and EU administered loan of all in all €20 billion (Lütz and Kranke 2014). 
government. It rather saw as its most urgent tasks to rein in the public debt and deficit, as defined by the IMF stand-by agreement signed in autumn 2008.

As the crisis unfolded, however, the question of foreign currency loans became increasingly pressing. After the Hungarian Central Bank had scrapped the currency band in 2008 and let the forint float, the latter massively depreciated against the Swiss franc, leaving forex-indebted homeowners in dire straits (IMF 2012: 19). This is the background of the second phase of crisis response under Viktor Orbán's FIDESZ government, which came to power in 2010. FIDESZ redesigned central elements of the Hungarian housing and housing finance system in the context of a deep economic and social crisis. In autumn 2011, it proclaimed a war against "debt slavery" (Bohle 2014; Johnson and Barnes 2015). The government's overtly nationalistic and antifinance-capital discourse aimed at pitting vulnerable households against foreign banks, thus generating support for its interventionist policies among all strata of society. The discourse was followed by deeds. In the course of its war against debt slavery, Hungary severed its ties with the IMF and sought to alleviate the burdens for households with foreign currency loans. Conversions of the forex loans at preferential exchange rates, an exchange rate protection mechanism, and finally, the mandatory conversion of almost all forex loans into Hungarian forint all were part of the government's toolkit. Banks were also forced to compensate borrowers for exchange rate spreads and unilateral interest rate changes. The costs of these measures were mostly pushed onto the banks, which already reeled from the burdens of hefty extra taxes (Bohle 2014; Johnson and Barnes 2015; Csizmady and Hegedüs 2016). It is no small wonder then that bank lending declined sharply. This contributed to the return of the woes of a peripheral housing regime. Mortgage finance has become a rare good, housing construction is stagnant, and people are once again stuck to their homes (EMF various issues).

\section{Iceland}

Iceland, as Schwartz (2011: 299) writes, "came late to the global party, drank too quick and hit the floor rather harder than larger economies". When the crisis erupted, the tiny country found itself with a hugely over-leveraged banking sector and population, and overvalued property prices. As Schwartz argues, "leveraging up without a reserve currency is a titanic mistake" (ibid 292). Its banks were indeed too big to be saved, and in contrast to Hungary, where parent companies of foreign banks were ready to take major losses, in the Icelandic case, British and Dutch depositors insisted on guarantees. Iceland had to turn to the IMF for emergency lending, which, together with the Nordic Central Banks also contributing to the bailout, administered the usual austerity medicine. ${ }^{9}$ The IMF also backed the British and Dutch governments' demand that Iceland compensate them for bailing out the Icesave depositors. Crisis and austerity triggered a wave of social unrest, which succeeded in ousting the government. During the protests, debt write-down emerged as one of the central demands (IMF 2012: 106). As in Hungary, homeowners who had borrowed in foreign currencies were particularly hard hit by the devaluation of Iceland's krona, which depreciated around $60 \%$ in the wake of the crisis.

\footnotetext{
9 The IMF and Nordic countries together offered a US\$4.6 billion loan to Iceland (Wade and Sigurgeirsdottir 2010: 22).
} 
In 2009, a center-left Social Democratic-Green coalition government came to power, for the first time in the country's history. This government undertook a number of interventionist steps in financial, currency and housing sectors, which fundamentally altered the previous financialized model (Hart-Landsberg 2013: n.p.). In terms of housing policies, the government adopted a number of measures fast in order to prevent overindebted homeowners from losing their homes. These included "a moratorium on foreclosure, a temporary suspension of debt service for exchange-rate and CPI-indexed loans, and rescheduling (payment smoothing) of these loans" (IMF 2012: 106). In addition to the government, the Supreme Court has played a major role in dealing with the legacy of foreign currency loans. In 2010, it ruled that foreign currency indexation had not been in line with existing laws, and loans had to be recalculated. According to Méndez Pinedo and Domurath (2015: 112), "the recalculation of illegal FX-indexed loans has so far been the most important tool for indebted and over-indebted Icelandic consumers to alleviate their debt burden." As in Hungary, a substantial part of the costs of loan restructuring was pushed onto the banks. As to future mortgage lending, a number of initiatives point to a more restrictive environment (Bank of Iceland 2014: 71).

\section{Ireland and Latvia: Embracing Financialization}

\section{Ireland}

Pundits and the media alike often depict Iceland's crisis management as the polar opposite of Ireland's. While Iceland let its banks go bust, Ireland saved them at enormous cost. While Iceland's economy profited from the substantial devaluation of the krona, Ireland had to accept the straightjacket of EMU and pursue internal devaluation. While Iceland pushed some of the costs of the crisis onto foreigners, Ireland had to internalize the costs to save German and French bondholders. Although some of the crisis response was related to domestic choices, Ireland's EMU membership weighed hard on the country's options.

In 2008, the Irish government reacted to large losses in the banking sector by issuing a blanket guarantee of the liabilities of all troubled banks, and subsequently by injecting massive capital in the banking sector and the nationalization of its banks. As a result, public deficit and debt soared and Ireland had to turn to the Troika of the EU, IMF, and ECB for emergency lending to avert a sovereign default. ${ }^{10}$ Thus, for Ireland, the Troika turned into the ultimate guardian of its troubled banks, and set harsh conditions for the rescue. The most contentious and weighty condition was that Ireland had to bail out senior bond holders (European Court of Auditors 2015).

The massive austerity that followed the bank guarantee and EU-IMF bailout led to a veritable crisis in housing and housing finance. Non-performing loans soared, and the Troika pushed Ireland for tougher eviction legislation (Irish Times, 11/12/2012). In this context, it is not surprising that Ireland - together with Latvia - is one of the few EU countries in which the number of evictions increased between 2010 and 2013 (Kenna et al. 2016). However, the absolute number of repossessions remains relatively low, mostly because banks have not been eager to foreclose property, as this step might result in real losses and bring the undercapitalization of banks into the open (Phillips

$\overline{10}$ The loan totaled some $€ 66$ billion (European Court of Auditors 2015: 17). 
2013). Social housing also suffered during the crisis. Already neglected for decades, the remaining meager budget was further retrenched in 2008-2014 (Department of the Environment, Community and Local Government 2014). Only in 2014 did the government outline a new strategy towards social housing. Most of the support, however, is not dedicated to public social housing, but rather subsidizes rental payments. This dovetails a more substantial change in the Irish housing regime, namely the rise of private rentals (Norris 2016). In 2011, almost one in five families lived in private rentals, and the proportion in cities is even higher (Threshold 2014: 3).

\section{Latvia}

Latvia's policy response to its banking and mortgage crisis has been most similar to that of Ireland. Its immediate response was overshadowed by the run on its biggest domestic bank, PAREX. In response to the run, the government took over majority control for a symbolic price. The costs of recapitalizing and the need for restructuring PAREX were the major reasons why the Latvian government turned to the IMF in 2008 (Aslund and Dombrovskis 2011: 35). At the same time, Latvia's currency came under tremendous pressure. The major focuses of the IMF-EU-Nordic bailout package were macroeconomic aspects of the crisis, including the exchange rate. ${ }^{11}$

A crucial policy decision of the Latvian government was to avoid devaluation of the lats and instead prepare for euro entry. This was a very controversial decision: a number of internationally renowned economists and the IMF team suggested that Latvia abandon its currency peg to regain competitiveness (Lütz and Kranke 2014). The Latvian government, however, decided not to heed this advice and instead engaged in one of the toughest austerity packages in Europe in order to defend the peg (interview with an economist, Riga, Latvia, 22 September 2015; Eihmanis 2017).

The severity of Latvia's adjustment was one of the major reasons for over-indebtedness. The government did little to help over-indebted homeowners. Under the pressure of banks, and also because mortgages were mostly held by more affluent segments of the population, it decided against public support for household debt restructuring (Erbenova et al. 2011: 16). Instead, banks restructured the loans, typically without reducing the overall value of the debt (ibid: 11). Austerity and market-based debt restructuring led to significant increase of evictions (Kenna et al. 2016: 61).

One of the most worrisome features for over-indebted homeowners was that "[I]n the case of mortgage default at the moment, banks could repossess the property, take second properties if owned, and also recoup further debt from the future earnings of the borrower" (Traynor 2009). Indeed, one of my interviewees stated: "There are in my opinion more people displaced by repossessions than by the early privatization" (interview with an economist, Riga, Latvia, 21 September 2015). Successive Latvian governments tried to change this by shifting some of the risks of underwater mortgages on the banks. These attempts failed because the Nordic banks put up huge resistance (Eglitis 2015).

Overall, despite a relatively fast recovery of the economy, mortgage lending has remained slow since the crisis broke out, while house prices have been increasing,

\footnotetext{
${ }^{11}$ Latvia's IMF-EU-Nordic countries loan was $€ 7.5$ billion, $40 \%$ of its GDP (European Court of Auditors 2015: 17). For a thorough discussion of the loan and conditionality, see Lütz and Kranke (2014).
} 
especially in Riga. This is mostly due to the Latvian government offering second residency for foreigners who buy real estate (Hendersen 2014). For locals, access to housing remains difficult, with unemployment still high, incomes low, and bank lending only cautiously (IMF 2016).

\section{Summary}

This section has argued that the crisis has revealed the hierarchical nature of coreperiphery financial relations. In light of a sudden stop of capital flows, none of the four countries were able to stabilize their economies on their own. The conditions set by the ultimate guardians of their transnationally integrated financial systems differed, as did domestic crisis responses. Thus, Hungary and Iceland have by and large rejected the previous paths of financialization, with Hungary's answer being more extreme, while Ireland and Latvia have mostly accepted the discipline of financialization. The concluding section will take a step back and ask how the different policy responses relate to the broader trajectories these countries have embarked upon, and what all of this tells of for the future of peripheral housing finance(ialization).

\section{Conclusions: the Past and Future of Peripheral Housing Finance}

Puzzled by the rapid increase of mortgage lending in a number of European peripheral countries, this paper has shed light on the trajectories of housing finance in four countries. I argued that a number of common themes run through the rapid build-up of mortgage debt. EU-induced external liberalization and deregulation, and in the East Central European cases, privatization of the banking sector washed these countries with excessive liquidity. Additionally, the integration into the European single market, economic area, or eurozone dramatically decreased the costs of borrowing for the peripheral countries and allowed them to escape their narrow domestic deposit base. An important share of international liquidity went into housing finance. In three of the four countries, inexperienced banks were at the origin of the mortgage booms, and in all countries, governments and supervisory authorities were either unwilling or unable (and typically both) to rein in banks and the risky lending boom.

Is there anything specific to these mortgage booms which make them peripheral? After all, the liberalization of mortgage finance, an increasing reliance on foreign funding, and regulatory forbearance have been the hallmark of mortgage booms prior to the crisis elsewhere, notably in the USA and UK (Fernandez and Aalbers 2016). First, I show that the nature of demand for housing finance differs. In Europe's East, high homeownership rates, virtually non-existing mortgage markets, and stagnant housing construction during the 1990s led to a pent-up demand for housing and housing finance (Bohle 2014). In Europe's North West, highly decommodified property-based welfare systems have become marketized (Norris 2016). This differs from the more sophisticated deepening of already commodified mortgage finance, and its expansion to subprime segments particularly in the USA.

Second, the form of internationalization of mortgage finance differs. In the four cases, banks were at the origin of mortgage booms. In Europe's East, transnational banks were dominantly financed by parent banks, whereas in the two Northwestern 
countries, domestic banks borrowed on wholesale markets via interbank lending. In contrast to the USA or UK, securitization of mortgages and their selling to institutional investors did not play a key role.

Third, all countries leveraged up internationally without the benefits of a reserve currency (Schwartz 2011). This is what made these countries particularly vulnerable to sudden stops and reversal in credit flows. The sudden reversals of credit flows shook the foundations of the peripheral financial systems, and their stabilization has revealed the hierarchical nature of peripheral financialization. None of the countries was strong enough to stabilize their financial systems on their own, and only during the crisis that it turned out who the ultimate guardian of their transnationally integrated financial systems was (Pistor 2009). The international constraints stemming from the conditionality of the ultimate guardians differed considerably across the cases. Arguably, Hungary was the country least constrained. Its banking sector only faced a liquidity crisis resulting from the turmoil in the foreign currency swap market (Aslund and Dombrovskis 2011). What is more, ultimately, the reliance on foreign banks allowed Hungary to outsource much of its troubles to the parent banks. This was also true for Latvia.

The constraints facing Ireland and Iceland were of higher magnitude, but of polar opposite nature. Iceland found out that no ultimate guardian was able or willing to stabilize its vastly oversized banking sector. Its own Central Bank was unable to act as lender of the last resort, and an international stand-by credit by the IMF and the Nordic countries helped to stabilize the economy, but only after the banking sector collapsed. In contrast, Ireland discovered that belonging to the eurozone does not provide shelter for peripheral countries in crisis. Because of the no-bailout clause of the Maastricht treaty, it found its access to capital markets blocked, while its Troika rescue package reflected concerns for the eurozone system as a whole, rather than the particular Irish woes. Therefore, Ireland had the harshest conditions for the revival of its defunct banking system.

What do these different constraints mean for the future of housing financialization? Table 3 below summarizes the findings. I have highlighted two issues: on the one hand, the policy responses through which each country tried to negotiate the international constraints and, on the other hand, the level of mortgage debt prior to the crisis. Thus, Hungary and Iceland rejected the previous paths of marketization of mortgages, while Ireland and Latvia submitted to the discipline of international finance. However, given the difference in the initial depth of their mortgage markets, the results of policy choices differed. The Hungarian policy response successfully reversed the path of housing financialization. Squeezing the banks certainly relieved upper middle class over-

Table 3 The future of peripheral housing financialization

\begin{tabular}{|c|c|c|c|}
\hline & & \multicolumn{2}{|l|}{ Domestic rejection of financialization } \\
\hline & & Yes & No \\
\hline \multirow[t]{2}{*}{$\begin{array}{l}\text { International } \\
\text { constraints }\end{array}$} & High & $\begin{array}{l}\text { Reduced financialization, but vulnerability } \\
\text { remains (Iceland) }\end{array}$ & $\begin{array}{l}\text { Financialization taken to a new level } \\
\text { (Ireland) }\end{array}$ \\
\hline & Low & $\begin{array}{l}\text { Voluntary return to peripheral housing } \\
\text { regime (Hungary) }\end{array}$ & $\begin{array}{l}\text { Unintended return to peripheral } \\
\text { housing regime (Latvia) }\end{array}$ \\
\hline
\end{tabular}


indebted homeowners, but it also led to a dramatic decline in mortgage lending. This was welcomed by the government, which sought to limit the overall role of finance in the economy and to direct bank lending towards productive capacities. As it did not offer comprehensive alternatives to homeownership or public housing finance, the consequence has been a return to the peripheral housing regime. Interestingly, the outcome was quite similar in Latvia. In the Latvian case, it was unintended. In contrast to Hungary, the Latvian authorities never sought to curtail lending or rein in the banking sector. Rather, a combination of more prudential international norms, more cautious lending by the international banks, and borrowers whose economic outlook is still not stable have driven out housing financialization, at least for the time being.

This contrasts with the Irish case. Banks remain major players in mortgage and housing markets. Here, policy responses have taken financialization of housing to the next level. Limited supply and rising house prices combine with tight mortgage lending to produce increasing wealth inequality, with a "generation landlord" increasing their housing capital at the costs of "generation rent" (Ronald et al. 2015; Regan 2016).

While there might be alternatives to returning to the peripheral housing regime, and the increasing inequality of wealth that the post-crisis phase of financialization produced, the Icelandic post-crisis pathway shows that this is a thin line to walk. The state took back control over mortgage finance, ruled out risky forms of peripheral financialization, and tried to revive public housing. At the same time, however, the IMF (2015 n.p.) has recently warned that "the loss-making government-owned Housing Financing Fund, which currently dominates the mortgage market, needs to be unwound as its business model is no longer viable and replaced by a financially viable successor housing program".

Acknowledgements I am grateful for comments from the workshop participants, and especially from László Bruszt, Niamh Hardiman, and Visnja Vukov. I also gratefully acknowledge the extensive comments by Manual Aalbers, Herman Mark Schwartz and one anonymous reviewer. All errors, inconsistencies, and loose ends are mine. This work was supported by the project 'European Legitimacy in Governing through Hard Times (\#649456-ENLIGHTEN), a European Commission Research and Innovation action under the Horizon 2020 Framework Program.

Open Access This article is distributed under the terms of the Creative Commons Attribution 4.0 International License (http://creativecommons.org/licenses/by/4.0/), which permits unrestricted use, distribution, and reproduction in any medium, provided you give appropriate credit to the original author(s) and the source, provide a link to the Creative Commons license, and indicate if changes were made.

\section{References}

Aalbers M, B. The financialization of home and the mortgage market crisis. Compet Chang. 2008;12(2):14866.

Aalbers MB. The financialization of housing: a political economy approach. New York: Routledge; 2016.

Aalbers MB, Christophers B. Centring housing in political economy. Housing, Theory and Society. 2014;31(4):373-94.

Allen J, Barlow J, Leal J, Maloutas T, Padovani L. Housing and welfare in southern Europe. Oxford: WileyBlackwell; 2004.

Ansell B. The political economy of ownership: housing markets and the welfare state. Am Polit Sci Rev. 2014;108(02):383-402. 
Aslund A, Dombrovskis V. How Latvia came through the financial crisis. Washington: Institute of International Economics; 2011.

Banai A, Kiraly J, Nagy M. "Home high above and home deep down below-lending in Hungary." SSRN scholarly paper ID 1939727. Rochester: Social Science Research Network; 2011. http://papers.ssrn. com/abstract $=1939727$

Bank of Iceland. 2014. Financial stability report. Vol. 14. Accessed October 10, 2016. http://www.cb. is/publications/publications/financial-stability/.

Barnes L, Wren A. The liberal model in the crisis: continuity and change in Great Britain and Ireland. In: Bermeo N, Pontusson J, editors. Coping with crisis: government reactions to the great recession. New York: Russell Sage Foundation; 2012. p. 287-324.

Becker J, Jäger J, Leubolt B, Weissenbacher R. Peripheral financialization and vulnerability to crisis: a regulationist perspective. Compet Chang. 2010;14(3-4):225-47.

Benediktsdottir S, Danielsson J, Zoega G. Lessons from a collapse of a financial system. Econ Policy. 2011;26(66):183-235.

Berthaud F, Colliac S. Which emerging countries have experienced a sudden stop of capital inflows during the recent crisis. Trésor-Economics. 2010;76:1-8.

Blanchard OJ, Griffiths M, Gruss B. Boom, bust, recovery: forensics of the Latvian crisis. Brook Pap Econ Act. 2013;2013(2):325-88.

Bohle D. Post-socialist housing meets transnational finance: foreign banks, mortgage lending, and the privatization of welfare in Hungary and Estonia. Rev Int Polit Econ. 2014;21(4):913-48.

Bohle D, Greskovits B. Capitalist diversity on Europe's periphery. Ithaca: Cornell University Press; 2012.

Bukeviciute L, Kosicki D. Real estate price dynamics, housing finance and relate macro-Prudential tools in the Baltics. ECFIN Country Focus. 2012;9:1-8.

Committee on Constitution, Justice, and Standing Order of the Hungarian Parliament (2012). Jelentése a 2002-2010 közötti lakossáagi deviza-eladósodás okainak feltárásáról, valamint az esetleges kormányzati felelösségvizsgálatá ['Report about the causes of and the possible governmental responsibilities in residential indebtedness in foreign currency between 2002-2010'], Budapest, February 13, http://www. parlament.hu/irom39/05881/05881.pdf

Csizmady A, Hegedüs J 2016. "Hungarian mortgage rescue programs 2009-2016.” In The Narodowy Bank Polski Workshop: Recent Trends in the Real Estate Market and Its Analysis. National Bank of Poland, Economic Institute. https://ideas.repec.org/b/nbp/nbpcha/2.html.

Decressin J, Fonteyne W, Faruqee H. Integrating Europe's financial markets. Washington: International Monetary Fund; 2007.

Dellepiane S, Hardiman N, Heras JL. 2013. "Building on easy money: The political economy of housing bubbles in Ireland and Spain.” UCD Geary Institute Discussion Paper 2013/18. http://irserver.ucd. ie/handle/10197/4929.

Department of the Environment, Community and Local Government. 2014. "Social Housing Strategy 2020: Support, Supply, Reform.” http://www.housing.gov.ie/housing/social-housing/social-housingstrategy/social-housing-strategy-2020

Égert B, Mihaljek D. Determinants of house prices in central and Eastern Europe. Comp Econ Stud. 2007;49(3):367-88.

Eglitis A. Nordic banks doubling down payments Spur Law's Defeat. Bloomberg.com, March 6, 2015. 2015. http://www.bloomberg.com/news/articles/2015-03-06/nordic-banks-doubling-down-payments-spur-laws-defeat.

Eihmanis E. Cherry-picking external constraints: Latvia and EU economic governance, 2008-2014. J Eur Public Policy. 2017;25:231-49. https://doi.org/10.1080/13501763.2017.1363267.

Ekholdt Christensen J. 2011. The economic crisis in Ireland, Iceland and Latvia. Monetary review, 1st Quarter 2011. Danish National Bank.

EMF. "Hypostat. A Review of Europe's Mortgage and Housing Markets." European Mortgage Federation. 2011; 2013; 2014 (Various years).

Enoch C, Ötker-Robe İ, editors. Rapid credit growth in central and Eastern Europe: endless boom or early warning? New York: Palgrave; 2007.

Epstein RA. When do foreign banks 'cut and run'? Evidence from west European bailouts and east European markets. Rev Int Polit Econ. 2014;21(4):847-77.

Erbenova M, Liu Y, Saxegaard M. Corporate and household debt distress in Latvia: strengthening the incentives for a market-based approach to debt resolution. International monetary fund. 2011.

Esping-Andersen G. Politics against markets: the social democratic road to power. Princeton: Princeton University Press; 1988. 
European Court of Auditors. "Special report No 18/2015: Financial assistance provided to countries in difficulties." 18/2015. Luxembourg. 2015. http://www.eca.europa.eu/en/Pages/DocItem.aspx?did=35016.

Fernandez R, Aalbers MB. Financialization and housing: between globalization and varieties of capitalism. Compet Chang. 2016;20(2):71-88.

Gros D, Alcidi C. Country adjustment to a 'sudden stop': does the euro make a difference? IEEP. 2015;12(1):5-20.

Hart-Landsberg M. Lessons from Iceland: capitalism, crisis, and resistance. Mon Rev;2013 65(5). https:/www.questia.com/read/1P3-3105420561.

Hay C, Riiheläinen JM, Smith NJ, Watson M. Ireland: The outlier inside. In The Euro at Ten: Europeanization, power, and convergence, edited by Kenneth Dyson, 182-203. Oxford University Press. 2008. http://econpapers.repec.org/RePEc:oxp:obooks:9780199208869.

Hegedüs J. Housing policy and the economic crisis-the case of Hungary. In: Forrest R, Yip NM, editors. Housing markets and the global financial crisis: the uneven impact on households. Cheltenham: Edward Elgar Publishing; 2011. p. 113-30.

Hegedüs J. Housing privatization and restitution. In: Hegedüs J, Lux M, Teller N, editors. Social housing in transition countries. New York: Routledge; 2013. p. 33-49.

Hendersen A. How to get second residency in Latvia-Real Estate or business. Nomad Capitalist (blog). March 19, 2014. 2014. http://nomadcapitalist.com/2014/03/19/buy-real-estate-latvia-get-secondresidency-passport/.

Henilane I. Review of existing and new long-term housing financial instruments in Latvia. In. Vilnius: VGTU Technika. 2016. https://doi.org/10.3846/bm.2016.11.

Honohan P. Euro membership and Bank stability-friends or foes? Lessons from Ireland. Comp Econ Stud. 2010;52(2):133-57.

International Monetary Fund (IMF). Republic of Latvia: selected issues. 2006. http://www.imf. org/external/pubs/cat/longres.cfm?sk=19984.0.

International Monetary Fund (IMF). World economic outlook 2012: Growth resuming, dangers remain. Washington, D.C: International Monetary Fund. 2012.

International Monetary Fund (IMF). IMF survey: Iceland makes strong recovery from 2008 financial crisis. March 13, 2015. 2015. https://www.imf.org/external/pubs/ft/survey/so/2015/car031315a.htm.

International Monetary Fund (IMF). Latvia. 2016 Article IV Consultation: Press Release; Staff Report; and Statement by the Executive Director for Latvia. IMF Country Report 16/171. 2016. http://www.imf. org/external/pubs/ft/scr/2016/cr16171.pdf.

Johnson J, Barnes A. Financial nationalism and its international enablers: the Hungarian experience. Rev Int Polit Econ. 2015;22(3):535-69.

Jordà Ò, Schularick M, Taylor AM. The great mortgaging: housing finance, crises, and business cycles. National Bureau of Economic Research. 2014. http://www.nber.org/papers/w20501.

Józon M. Country report Hungary. In Consumer debt and social exclusion in Europe, edited by H-W Micklitz, I Domurath 85-98. Farnham, Surrey, England; Burlington, VT, USA: Ashgate. 2015.

Kelly J, Everett M. Financial liberalisation and economic growth in Ireland. Central Bank and Financial Services Authority of Ireland, Quarterly Bulletin Article, Autumn 2004, 91-112. 2004.

Kenna P, Benjaminsen L, Busch-Geertsema V, Nassare-Aznar S. Pilot project-Promoting protection of the right to housing-Homelessness prevention in the context of evictions. European Commission, Directorate-General Employment, Social Affairs and Inclusion. 2016.

Lane PR. The funding of the Irish domestic banking system during the boom. unpublished manuscript. 2015. http://www.ssisi.ie/SSISI2015_LANE_16january2015_all.pdf.

Lapavitsas C. Profiting without producing: how finance exploits us all. London: Verso; 2013.

Lütz S, Kranke M. The European rescue of the Washington Consensus? EU and IMF lending to Central and Eastern European countries. Rev Int Polit Econ. 2014;21(2):310-38.

McDonald F, Sheridan K. The builders: how a small group of property developers fuelled the building boom and transformed Ireland. Dublin: Penguin; 2008.

Méndez Pinedo E, Domurath I. Country report Iceland. In Consumer debt and social exclusion in Europe, edited by H-W Micklitz, I Domurath, 85-98. Farnham, Surrey, England; Burlington, VT, USA: Ashgate. 2015.

Mitra P, Selowsky M, Zalduendo J. Turmoil at twenty: recession, recovery, and reform in central and Eastern Europe and the former Soviet Union. Washington: World Bank Publications; 2010.

Norris M. Property, family and the Irish welfare state. Cham: Springer; 2016.

Norris M, Coates D. How housing killed the Celtic Tiger: anatomy, consequences and lessons of Ireland's housing boom and bust, 2000-2009. Dublin: School of Applied Social Science, University College Dublin, Working Paper, 2010. http://www.ucd.ie/t4cms/wp15\%20how\%20housing\%20killed\%20the\%20 celtic\%20tiger.pdf. 
Osa I. Housing Finance in Latvia. In Housing Finance Markets in Transition Economies, 185-207. 2005. OECD Publishing. http://www.oecd-ilibrary.org/finance-and-investment/housing-finance-markets-intransition-economies/housing-finance-in-latvia_9789264010178-15-en.

Phillips M. Welcome to Ireland, where mortgage payments are apparently optional. Quartz. 2013. http://qz. com/50615/welcome-to-ireland-where-house-payments-are-optional-apparently/. Accessed Nov 62014.

Pistor K. Into the void: governing finance in central \& Eastern Europe. SSRN Scholarly Paper 355. Columbia Law and Economics Working Paper. New York: Columbia University. 2009. http://papers.ssrn. com/abstract=1476889.

Pistor K. Governing interdependent financial systems: lessons from the vienna initiative. J Glob Dev. 2012;2(2): Article 4):25.

Regan A. The housing crisis is all about the politics of debt. The Irish Economy (blog). July 20, 2016. 2016. http://www.irisheconomy.ie/index.php/2016/07/20/the-housing-crisis-is-all-about-the-politics-of-debt/.

Ronald R, Kadi J, Lennartz C. Homeownership-based welfare in transition. Crit Housing Anal. 2015;2(1):5264. https://doi.org/10.13060/23362839.2015.2.1.176.

Rózsavölgyi R, Kovács V. Housing subsidies in Hungary: curse or blessing. ECFIN Country Focus. 2005;2(18):1-6.

Schelkle W. A crisis of what? Mortgage credit markets and the social policy of promoting homeownership in the United States and in Europe. Polit Soc. 2012;40(1):59-80.

Schwartz H. Subprime nation: American power, global capital, and the housing bubble. Cornell University Press. 2009.

Schwartz H. Iceland's financial iceberg: why leveraging up is a titanic mistake without a reserve currency. European Political Science. 2011;10(3):292-300.

Schwartz H, Seabrooke L. Varieties of residential capitalism in the international political economy: old welfare states and the new politics of housing. Comp Eur Polit. 2008;6(3):237-61.

Stephens M, Lux M, Sunega P. Post-socialist housing systems in Europe: housing welfare regimes by default? Hous Stud. 2015;30(8):1210-34.

Sveinsson J-R. Housing in Iceland in the aftermath of the global financial crisis. In: Forrest R, Yip NM, editors. Housing markets and the global financial crisis: the uneven impact on households. Cheltenham: Edward Elgar Publishing; 2011. p. 57-73.

Tax Justice Network. How Ireland became an offshore financial centre. November 11, 2015. 2015. https://www.taxjustice.net/2015/11/11/how-ireland-became-an-offshore-financial-centre/.

Threshold Buy-to-let mortgage arrears: measures needed to protect homes of tenants and stability of private rented sector. Submission to Joint Oireachtas Committee on Finance, Public Expenditure and Reform. Dublin: Threshold Charity. 2014.

Traynor I. Latvia threatens foreign banks with huge losses. The Guardian, October 7, 2009, sec. Business. 2009. https://www.theguardian.com/business/2009/oct/07/latvia-crisis-mortgage-debt.

Viken BS. The birth of a system born to collapse: laissez-faire the Icelandic way. European Political Science. 2011;10(3):312-23.

Wade R, Sigurgeirsdóttir S. Lessons from Iceland. New Left Rev II. 65 (October):5-29. 2010.

Whitehead C, Scanlon K, Lunde J. The impact of the financial crisis on European housing systems: a review. SIEPS. 2014. http://www.sieps.se/sites/default/files/Sieps\%202014_2\%20webb_NY.pdf.

Dorothee Bohle is Professor of Political Science at the European University Institute in Florence. Her research focusses on comparative political economy with a special emphasis on East Central Europe. Her book "Capitalist Diversity on Europe's Periphery" (co-authored with Béla Greskovits, Cornell University Press, 2012) has received the 2013 Stein Rokkan Prize for Comparative Social Research. Her work has been published, among others, in Comparative Politics, Review of International Political Economy, New Political Economy, West European Politics and Journal of Democracy. 